International Journal of English Language Studies (IJELS)

ISSN: 2707-7578

DOI: 10.32996/ijels

Website: https://al-kindipublisher.com/index.php/ijels

\title{
Literature Circle: A Strategy in Improving Critical Thinking Skills
}

Mary Nerissa T. Castro, MST

University of Cebu, College of Teacher Education/SHS Department, Philippines

Corresponding Author: Mary Nerissa T. Castro, MST, E-mail: maryner1995.castro@gmail.com

\section{ARTICLE INFORMATION}

Received: December 08, 2020

Accepted: February 05, 2021

Volume: 3

Issue: 2

DOI: 10.32996/ijels.2021.3.2.9

\section{KEYWORDS}

Literature circle, improving critical thinking skills, quasi-experimental method, University of Cebu-

Banilad

\section{ABSTRACT}

Reading is the prime foundation of one's academic and social status. However, this vital skill is what most students lack attention and interest. As a result, it deteriorates their critical thinking skills. To address the problem, Harvey Daniel introduced his literature circle strategy. It showcases different features that likely aid student's struggles in the aspect of reading. This study, therefore, aims to determine the effectiveness of the literature circle strategy in improving critical thinking skills in reading among students at the University of Cebu-Banilad Campus. The study utilized a quasi-experimental method where the $48 \mathrm{ABM}$ Grade 12 research subjects of the study were divided into two groups, namely: control and experimental. Strategies employed in these groups were different. The traditional method was practiced in the control group, while the literature circle strategy was implemented in the experimental group. For data gathering, a researcher-made test about the short story "Dead Stars" by Paz Marquez Benitez was used as the main instrument. Another short story entitled "The Small Key" by Paz Latorena was used as a springboard in the implementation of strategies for both groups. Statistical treatments used for data analysis were simple percent, $\mathrm{t}$-test for Correlational Samples, and t-test for Two Independent Samples. Findings revealed that in measuring subjects' critical thinking skills in reading, there is a significant difference between the posttest performances of the groups. The research subjects under experimental group performed higher than the control group. The study concludes that literature circle strategy is effective in enhancing student's critical thinking skills in reading.

\section{Introduction}

Literature serves as a channel for cultural and life appreciation. It can also access and reflect on various cultural backgrounds and norms of which students make connections of their thoughts and feelings as they read. Teaching literature can be laborious if students are not motivated to read. Reading can expand vocabulary range, develop critical thinking skills, and cultivate one's understanding of other cultures.

Reading, however, has been a long-term struggle of teachers as they deal with students who lack skills, literacy, motivation, and independence to read. This declining interest is evident in the study conducted by Social Weather Stations in May 2012. It revealed that the overall number of Filipino adult readers fell to $88 \%$ from $92 \%$ in 2007 and $94 \%$ in 2003. The results also noted that there was an abatement in readership in four types of reading materials, namely: books, magazines, comics, and newspapers (Roque, 2016).

The English instructors at the University of Cebu- Banilad have been using the usual approach in teaching literature. For instance, they give reading assignments with hope and assumptions that students will complete the reading task. The method does not seem to fit the holistic development of the child and does not offer an opportunity for developing critical thinking skills. Thus, a literature circle strategy which encourages students to read independently is introduced. It is done through a small group discussion where students gather to enhance literacy by discussing a piece of literature in depth.

The researcher, who is a teacher by profession, has been teaching literature throughout her teaching career. It has been observed that students are struggling to derive in-depth analysis and interpretation of any given texts. Therefore, the researcher

K C AL-KINDI CENTER $\mathbf{R}$ FOR RESEARCH AND R D DEVELOPMENT Your gateway to world-class research

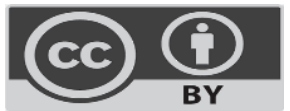

Published by Al-Kindi Center for Research and Development. Copyright (c) the author(s). This open access article is distributed under a Creative Commons Attribution (CC-BY) 4.0 license 
would explore the effectiveness of literature circles, as means to improve students' critical thinking skills in reading.

This study is anchored in Lev Vygotsky's Zone of Proximal Development, Johnson and Johnson's Cooperative Learning and Deci and Ryan's Self-determination Theory.

Zone of Proximal Development (ZPD) by Lev Vygotsky asserts that learning should match the child's level of development. Hence, to better comprehend the relationship between the two, it is necessary to distinguish the actual and potential levels of a child. The actual level refers to those achievements that a child can perform or demonstrate independently, whereas potential levels relate to tasks a child is capable with an adult's succor and collaboration with peers (McLeod, 2018). The assistance that a child needs in a potential level is best played and explained in the concept of more knowledgeable other.

Vygotsky regarded that learning and development are best understood when the focus is on the examination of the process of how one learns when engaged in shared tasks rather than the measurement on what the learner can accomplish independently. Development in this concept occurs when a child learns general concepts and principles that can apply to new tasks and problems (Lantolf, 2000). Productive interactions and aligning instructions toward the ZPD allow learners to develop skills and strategies that will eventually apply in their situations. It guides the learner with instructions on how to perform the task and organize the newly gained knowledge in their existing mental schemas of which he/she will later use in further complicated and advance performance independently.

According to Johnson and Johnson (2005), cooperative learning is when students work together in small groups to accomplish a shared set of learning goals which aid in maximizing their own and each other's learning. For the lesson to be interdependent, five primary elements must be examined and carefully structured namely: positive interdependence, promotive interaction, individual accountability, social skills, and group processing (Johnson, Johnson \& Holubec, 2013).

Within cooperative activities, there is a positive interdependence among students' goal attainments if each member in the group has also reached the learning goal. The idea accounts that what helps one member helps all group members and what hurts one group member hurts all (Johnson \& Johnson, 2008).

Promotive interaction, on the other hand, is achieved if each member shares mutual understanding, either academically or personal. The support and assistance that each member has, bring openness and active interaction among individuals within the group (Johnson, Johnson \& Holubec, 2013).

The success rate of this method, however, does not only rely on the same goal that each member is eyeing but also need an individual's participation and meaningful demonstration on each other's knowledge and skills. Contributing a fair share of the work toward the group's goal and providing each other with feedback or any sort of assistance simulate members to feel individually accountable with their fellow group members (McCafferty, Jacobs \& Iddings, 2006).

The groups formed, according to Ashman and Gillies (2003), worked on a variety of activities which continuously build effective communication as each member freely communicate their ideas or concerns on achieving their goals through group processing. As students do this, specific episodes of caring, sharing, taking turns, trust-building, and other social skills were frequently observed among members as they surfaced towards interactions which deepen their interpersonal sensitivity and understanding (McConnell, 2014).

With cooperative learning, students can have opportunities to assess, evaluate, and acknowledge each other's understanding, which motivates them to learn. The more skills engaged when students interact, the higher their achievements will be (Johnson \& Johnson, 2008). Hence, it is the interaction that drives students to acquire learning.

Self-Determination Theory (SDT) involves intrinsic motivation which was developed by Ryan and Deci (2000). This represents a broader framework for the study of human motivation, personality, and functioning. Intrinsic motivation refers to one's inner pleasure, which often leads to high levels of engagement and performance (Seifert \& Sutton, 2012). According to Legault (2017), the theory proposes three basic psychological human needs for facilitating optimal functioning, constructive social growth, and personal well-being: autonomy, competence, and relatedness.

In SDT theory, the basic human needs are linked to one's motivation and are necessary conditions for the maintenance of intrinsic motivation (Niemiec \& Ryan, 2009). The need for autonomy refers to the experience of behavior as reflectively selfendorsed. Students become autonomous when devotion and energy towards their studies are self-inflicted. Hence, acknowledgment of perceptions and opportunities for self-direction were found to heighten intrinsic motivation because they allow people a more prominent feeling of autonomy. Studies have further shown that autonomy-supportive teachers (in contrast to controlling) reported to increase student's curiosity, excitement for a challenge, and self-esteem (Ryan \& Deci, 2000).

On the other hand, the need to feel efficacious or skilled in one's pursuit of goals is pinned to competence. According to Deci and Ryan (2004), when students feel competent, they feel to meet the challenges and are in pursuit of more trials. It allows them 
to build mastery and to unravel new things. Self-determined students are more likely motivated to achieve; hence, providing appropriate tools and feedback when students perform well promote success and their feeling of efficacy. Accordingly, feedback serves as basis for the learners to monitor their learning by providing relevant information on how to master the tasks at hand. Moreover, introducing learning activities that are optimally challenging allow and expand students' academic capabilities (Niemiec \& Ryan, 2009).

Lastly, SDT also flourished a sense of security and relatedness. It is very essential for students to feel a sense of belonging and connectedness with others (Deci \& Ryan, 2004). In the classroom, relatedness is deeply associated when a student feels that the people around genuinely like, respect, and value him or her. Students who report such relatedness are more likely to exhibit excitement and integrated regulation for the difficult tasks involved in learning, whereas those who feel disconnected or rejected are more likely to move away (Mata et al., 2009).

Grounded by these different theories and their highly remarkable principles, Harvey Daniels (as cited in Stabile, 2009) proposed a new strategy, the so-called literature circle. It is a small peer-led discussion where students gather to discuss a piece of literature in-depth and to guide each other throughout the text. This peer-led discussion, according to Sandmann and Gruhler (2007), ignites questions driven from the text in which students critically express and value each other's perspectives to those questions, thus, creating a literate and interpretive community. It is also a great source of motivation, for it encourages thoughtful discussions and engagement of readers to love reading. It gives students opportunities to enhance their critical thinking skills and reflectivity as they read, discuss, and respond to a text (Ericson, 2001). In circles, according to Daniels (2002), participants have their roles (connector, questioner, illustrator, word wizard, etc.) rotating in every session and come to the group with notes needed to perform the job (as cited in Straits \& Nicholas, 2006). However, Peterson and Belizaire (2006) discussed that students do not need to rely on role sheets to help guide their discussions, for they often got too focused on completing the sheets and spent less time on broadening and putting thought to their group discussions.

As described by Moses (2009) and Noe (2013), this strategy is flexible and applicable in many types of learners, ages, and classrooms. The implementation of it is different in every classroom, for it is not a specific program and has no fixed recipe. It is 'teacher by design' that will provide students with modeling and structure. Hence, educators adapted and redefined this strategy in different ways (Noe, 2013). The following are some of the fundamental features of literature circles:

Students Choose Their Reading Material. Letting students pick their own choice of book is equally developing their sense of independence towards reading. Good teaching is when teachers intuitively provide students with choices in reading and discussing books. Hence, for reading to become a lifelong habit and deeply owned skill, it has to be voluntary, anchored in feelings of pleasure.

Groups Meet on a Regular, Predictable Schedule. Literature circle is not introduced as a one-time-only strategy in the classroom setting. It needs proper internalization of procedures, norms, and independency letting teachers and students to have this strategy in a regular schedule and not in an occasional treat. They also have to acknowledge that this is a long-term classroom investment. The meeting schedules of students are highly vital and encouraged. Each session needs a great amount of time to open up a natural conversation among members paving a way of having in-depth understanding and discussions of the book.

Students' Domination in Topic Discussion. In literature circles, students develop their ownership towards reading through selecting issues for discussion and sharing their views among fellow readers. They are in charge of their thinking and discussion helping them to become literary individuals and intellectually independent.

Written Notes to Guide both Reading and Discussions. Students, in circles, write their own thoughts and responses to the text and often used these as their starting point for conversation and sharing. After students have finished their circle, they write their own thoughts about the discussion. They reflect on tasks they did and determine what to improve and to strengthen. This allows students to be aware and to have full control of their own leaning like a mature adult reader.

Teachers as Facilitator. The teachers' work in literature circles is complex and essential. Aside from small briefing of introducing the strategy, most roles played are supportive, organizational and managerial. A teacher can also play a key role such as fellow reader where she joins a certain group and shares his/her honest ideas about the book (Daniels, 2002).

Literature Circle is an excellent practice for analytical skills, which helps learners become critical thinkers. As they immerse themselves in the process, they scrutinized the text, look for connections to the real world, make cultural assumptions towards the characters and to the author, situate themselves of why characters behave as they do, and evaluate interpretations in a context-based manner (Brown, 2009). The notion is further supported by Yang (2002), describing the strategy that can enhance one's self-evaluative stance, personal responses, and judgments from the readers. It heartens readers to draw logical inferences or conclusions from the text read, linking to their personal experience. Henceforth, the literature circle strategy does not only 
ignite students' interest in reading but also sharpens their critical thinking skills.

Critical thinking, according to Paul and Elder (2019), is a self-directed, self-monitored, and self-corrective thinking. It involves a series of complex self-thought processes to solve problems effectively and requires standards of excellence (Fisher, 2011). A critical thinker suspends judgment, exclude jumping to conclusions, avoid impulsive thinking, and does not settle for a superficial level of interpretation (McPeck, 2016). With all the mentioned features, students need to apply critical thinking towards reading. Through this, readers do not recognize not only what a text says, but also how the text is portrayed. To read critically, one must analyze, interpret, and find evidence on the read text (Kurland, 2000).

In light of these, different studies across the globe investigated the effectiveness of literature circle strategy in cultivating critical thinking skills and were put under meticulous observations. Most of it stresses the positive effect of literature circles both in qualitative and quantitative research.

Irawati (2016) conducted quasi-experimental method to see the effect of literature circle in improving reading comprehension of students. The results showed that literature circle has positive effect on students' literal and inferential reading comprehension covering identifying directly stated main ideas, finding explicit information, determining subject matter, and drawing inferences.

Brown (2009) also revealed that the literature circle strategy helped in developing students' critical thinking abilities. The study focused on the usage of various works of literature showcasing global issues context. The strategy itself has aid English as a Foreign Language (EFL) readers in becoming more mature and critical thinkers as they unravel the context of each assigned text by evaluating various characters' behavior. They based not solely within the context of the story but also in the context of the current real-world situations.

A similar study conducted by Liao (2009) also shows the effectiveness of the literature circle in enhancing English as a Foreign Language (EFL) Taiwanese students' critical thinking skills as the study gives ample opportunities for students to practice and answer higher-order thinking questions. The efficient learning tool for critical thinking, the regular and prolonged practice of connecting reading with reflection, has created a supportive and collaborative atmosphere.

Karatay (2017) conducted another study that was carried out as action research to utilize the literature circle strategy in improving students' text analyzation skills- in finding the topic, main idea, and keywords using expository texts. Based on the results utilizing pretest and posttest exams, the literature circle is operative in developing students' abilities to find the theme, main idea, and keywords in a text. The students also pointed out that the implementation of this strategy increased their selfconfidence, cooperative learning, critical thinking, reading objectively without bias, and independent reading skills.

In connection with the incentive that students have shown towards reading, a study conducted by Whittingham (2014) showed the effectiveness of literature circle strategy in motivating students to complete more assigned reading material using nonfiction texts. Due to the open-ended questions provided in the survey, results showed that the literature circle gave them the purpose of reading a text and guided them on which parts of the text they need to focus further.

Stabile (2009) specifically focused on struggling readers to assess how the literature circle strategy can help them to become more engaged and reflective. The findings of the study noted that the literature circle strategy is useful for struggling readers. The following conclusions were established: through literature circles, students have ownership on their reading; literature circles provide students with a small intimate setting; and lastly, the strategy aids students to have in-depth knowledge of the text read for they were using notes throughout the process.

The theories and works of literature presented have provided insights and distinct features of the literature circle strategy. It discusses how the strategy aids students' reading literacy as they share their knowledge, perceptions, and reflections, towards their group. Hence, this research on literature circle would be a great strategy in improving critical thinking skills.

\section{Purpose of the Study}

This study aimed to determine the effectiveness of literature circle strategy in improving critical thinking skills among Grade 12ABM students in University of Cebu- Banilad Campus, S.Y. 2019-2020.

Specifically, the study sought to answer the following questions:

1. What are the pretest performances of the control and experimental groups?

2. What are the posttest performances of the control and experimental groups?

3. Is there a significant difference between the pretest performances of the control and experimental groups?

4. Is there a significant difference between the pretest and posttest performances of the control and experimental groups?

5. Is there a significant difference between the posttest performances of the control and experimental groups? 
The following null hypotheses were tested at 0.05 level of significance:

Ho1: There is no significant difference between the pretest performances of the control and experimental groups.

$\mathrm{Ho}_{2}$ : There is no significant difference between the pretest and posttest performances of the control and experimental groups.

$\mathrm{Ho}_{3}$ : There is no significant difference between the posttest performances of the control and experimental groups.

\section{Research Design and Method}

The study utilized the quasi-experimental method using Literature Circle Strategy in improving critical thinking skills of Grade 12ABM students of the University of Cebu- Banilad Campus, Cebu, Philippines-Senior High School Department.

\subsection{Research Subjects}

The research subjects of this study were 48 Grade 12 students who took up Accountancy, Business, and Management (ABM). They were enrolled in 21st Century Literature from the Philippines and the World (English 4) and belong to one class. Subjects were then divided into two groups, namely the control group and the experimental group. The grouping was based on their age, gender, and final grade in their English 2 subject last school year.

Table 1 shows how the subjects were paired and grouped in the study.

Table 1: Pairing of the Research Subjects

\begin{tabular}{|c|c|c|c|c|c|c|c|}
\hline \multicolumn{4}{|c|}{ Control Group } & \multicolumn{4}{|c|}{ Experimental Group } \\
\hline Subjects & Age & Gender & Grade & Subjects & Age & Gender & Grade \\
\hline A & 17 & $\mathrm{~F}$ & 97 & AA & 18 & $\mathrm{~F}$ & 96 \\
\hline B & 17 & $M$ & 94 & BB & 17 & $\mathrm{~F}$ & 94 \\
\hline C & 17 & $\mathrm{~F}$ & 94 & CC & 17 & $\mathrm{~F}$ & 94 \\
\hline D & 18 & $\mathrm{~F}$ & 94 & DD & 17 & $\mathrm{~F}$ & 94 \\
\hline E & 17 & $\mathrm{~F}$ & 93 & $\mathrm{EE}$ & 17 & $\mathrm{~F}$ & 94 \\
\hline $\mathrm{F}$ & 17 & $\mathrm{~F}$ & 93 & $\mathrm{FF}$ & 17 & $\mathrm{~F}$ & 93 \\
\hline G & 17 & $\mathrm{~F}$ & 92 & GG & 17 & $\mathrm{~F}$ & 92 \\
\hline $\mathrm{H}$ & 18 & $\mathrm{~F}$ & 92 & $\mathrm{HH}$ & 17 & $\mathrm{~F}$ & 92 \\
\hline I & 18 & $\mathrm{~F}$ & 91 & $\|$ & 17 & $\mathrm{~F}$ & 91 \\
\hline J & 17 & $\mathrm{~F}$ & 91 & JJ & 17 & $\mathrm{~F}$ & 91 \\
\hline K & 17 & $\mathrm{~F}$ & 91 & KK & 18 & $\mathrm{~F}$ & 91 \\
\hline L & 18 & $\mathrm{~F}$ & 91 & LL & 17 & $\mathrm{~F}$ & 91 \\
\hline$M$ & 17 & M & 90 & MM & 17 & $M$ & 90 \\
\hline $\mathrm{N}$ & 17 & $\mathrm{~F}$ & 90 & NN & 17 & $\mathrm{~F}$ & 90 \\
\hline $\mathrm{O}$ & 18 & $\mathrm{~F}$ & 90 & O० & 18 & $\mathrm{~F}$ & 90 \\
\hline$P$ & 20 & $\mathrm{~F}$ & 90 & PP & 17 & $M$ & 90 \\
\hline Q & 17 & M & 90 & QQ & 18 & $\mathrm{~F}$ & 90 \\
\hline $\mathrm{R}$ & 18 & $\mathrm{~F}$ & 89 & $\mathrm{RR}$ & 17 & $\mathrm{~F}$ & 89 \\
\hline S & 16 & $\mathrm{~F}$ & 89 & SS & 17 & $\mathrm{~F}$ & 89 \\
\hline $\mathrm{T}$ & 17 & $\mathrm{~F}$ & 89 & $\mathrm{TT}$ & 18 & $\mathrm{~F}$ & 89 \\
\hline$U$ & 16 & $M$ & 88 & UU & 18 & $\mathrm{~F}$ & 89 \\
\hline $\mathrm{V}$ & 18 & $\mathrm{~F}$ & 87 & VV & 18 & M & 88 \\
\hline W & 17 & $\mathrm{~F}$ & 87 & WW & 17 & $\mathrm{~F}$ & 87 \\
\hline$x$ & 18 & $\mathrm{~F}$ & 86 & $x X$ & 17 & M & 84 \\
\hline \multirow[t]{2}{*}{ Total/ Ave. } & 417/ & $M=4$ & 2178/ & & $415 /$ & $M=4$ & 2178/ \\
\hline & 17.38 & $F=20$ & 90.75 & & 17.29 & $F=20$ & 90.75 \\
\hline SD & & & 2.59 & & & & 2.64 \\
\hline
\end{tabular}

Based on the data gathered in Table 1, the majority of the subjects were females (20) in both control and experimental groups. Most of the research subjects as well had similar age range from 16-18, and their final grades in English 2 have accumulated the same average result.

\subsection{Research Procedures}

To conduct the study, the researcher obtained authorization from the principal of the University of Cebu-Banilad Campus- Senior High School Department. The researcher personally conducted the study, for she handles English 4, and the research subjects were under her supervision. In the first meeting, prior to the actual gathering of data, the researcher gave a brief background of 
the notable authors in the Philippine contexts and their respective works. The elements of a short story as well were discussed to understand how these significantly contribute toward profound analysis and understanding of any texts read. Before the period ends, the researcher divided the class into control and experimental groups based on their age, gender, and final grade in the English 2 subject. The subjects were also asked to read the short story, "Dead Stars" as their assignment. In the second meeting, the researcher administered a pretest for both control and experimental groups to determine the subjects' initial level of critical thinking skills. During the pretest, subjects read the short story "Dead Stars" by Paz Marquez Benitez for about 30 minutes. After this, the copies were taken from them, and another 30 minutes allotment for answering the researcher-made test. The pretests of the two groups were gathered by the researcher and were evaluated by an eligible statistician. Soon after the pretest, the control and experimental groups were taught using different strategies. The conveyance of these strategies was done alternately in separate meetings since the research subjects of the study belong to one class. Also, during the implementation of strategy in a specific group, research subjects from the other group were asked to be in the library or spare classrooms and were tasked to do activities regarding the short story "The Small Key". In the third meeting, the control group used the conventional approach to teaching literature using the springboard "The Small Key" by Paz Latorena. The researcher explained some thematic, stylistic features of the text and literary content. The students tried to interpret the literary, social, political, and historical context of the text. Lectures, reading of notes, and explanations were utilized in the discussion. In the fourth to fifth meetings, the experimental group used the literature circle strategy utilizing the same short story "The Small Key". During this session, the researcher introduced the idea of the literature circle and the procedures in implementing this strategy. Then, the research subjects were grouped into five, consisting of 4-5 members. Intervention guide questions (see Appendix C) were handed in during the implementation process based on their focus and task to profoundly discuss the text: Group 1: Characters, Group 2: Setting, Group 3: Plot, Group 4: Symbols, and Group 5: Theme. The group was given the freedom to choose their desired topic for an indepth discussion of the story. While the students were sharing, the researcher roamed around to monitor the discussions. Throughout the procedure, the main features/procedures of the literature circle introduced by Daniels (2002) and Moses (2009), were strictly followed such as students choose their topic for the material, groups met on a regular and predictable schedule on students' domination in the topic discussion, and notes to guide students' deliberations, and the teacher acted as a facilitator. After all the procedures, posttest was administered to both groups. The researcher-made test (see Appendix A) that was utilized in the pretest was given once more. The posttest scores of both groups were gathered and evaluated by the same statistician. This is to know to what extent the students have progressed.

\subsection{Data Collection tools}

A researcher-made test about the short story "Dead Stars" by Paz Marquez Benitez was used as the main instrument of this study (see Appendix A). It served as the pretest and posttest exam of both control and experimental groups. The selection of the literary text was based on the curriculum guide in $21^{\text {st }}$ Century Literature from the Philippines and the World (English 4) showcasing renowned canonical Filipino works. The underlying moral lesson of the story and the comparative plot to the recent Filipino situation somehow serve as an eye-opener for students to do some reflections on making decisions and implications of emotions. Moreover, the text itself is quite complicated. Hence, profound analysis and a closer reading of the material are highly needed. The structure of the test was selected-response assessment specifically multiple choice. It comprised 20 questions that would assess subjects' knowledge and reasoning. Each item of the test was structured prudently to highly engage critical analysis. The qualitative interpretation of the subjects' critical thinking level and its corresponding scores were based on the following scoring range:

$\begin{array}{cc}\begin{array}{c}\text { Score Ranges } \\ 20-16\end{array} & \begin{array}{c}\text { Categories } \\ \text { Very Good } \\ 15-11\end{array} \\ 10-6 & \text { Good } \\ 5-0 & \text { Fair } \\ & \text { Poor }\end{array}$

Pilot testing is of paramount importance to ensure and increase the practicality, validity, and reliability of the main instrument. Accordingly, the researcher-made test was pretested to 48 students from the same strand of the target sample of the study. The pilot testing of the study aided the researcher to verify students' difficulties and lacks in dealing with the items which ensure more completeness and clarity of the instrument. The statistical tool used to find out the reliability of the test was Cronbach's Alpha (see Appendix B). Another short story entitled "The Small Key" by Paz Latorena was used in both control and experimental groups. It was done to assess the effectivity of each strategy used. The selection of the short story was based on the curriculum guide of the English 4 subject-21st Century Literature from the Philippines and the World, showcasing different renowned Filipino authors.

\subsection{Data Analysis}

The data gathered were subjected to statistical treatment to facilitate the interpretation of the results. Simple Percent was used 
to categorize the level of proficiency of the participants in their pretest and posttest performances both for the control and experimental groups. The $t$-test for Correlational Samples was used to determine the significant difference between the pretest and posttest performances of the control and experimental groups. Lastly, the t-test for Two Independent Samples was used to determine the significant difference between the posttest performances of the control and experimental groups.

\section{Results and Discussion}

This section presents and proves the proposition of the data gathered by the researcher on the effectiveness of the literature circle strategy in enhancing critical thinking skills among ABM students of the University of Cebu-Banilad Campus- SHS Department. The sources of data were scores garnered by the research subjects in the researcher-made test showcasing "Dead Stars" by Paz Marquez Benitez. The results were presented in tabular form with corresponding analysis and interpretation.

\subsection{First Sub-Problem: Pretest Performances of the Control and Experimental Groups}

The results of pretest performances of the control and experimental groups were tabulated in Table 2 to compare subjects' performances before the implementation of strategies used in each group when teaching literature.

Table 2. Pretest Performances of the Control and Experimental Groups

As shown in Table 2, when comparing and contrasting the pretest performances of both control and experimental groups, the following were observed: the same number of subjects (11) were under fair and good categories and the corresponding percentages/frequencies between poor and very good were quite similar and failed to show major difference of results.

The similarity of results drawn from the table contributed an additional indicator that the two groups were valid samples and were both struggling in their performance. This also brought enlightenment and realization that the research subjects lack the skills, critical analysis, motivation, and independence to read. Hence, it further acknowledges the essentiality of implementing the literature circle as an intervention to boost their performance. This strategy gives them opportunities to enhance their critical thinking skills and reflectivity as they read, discuss, and respond to a text (Ericson, 2001).

\subsection{Second Sub-Problem: Posttest Performances of the Control and Experimental Groups}

Table 3 shows the posttest performances of the control and experimental groups to compare research subjects' performances after

\begin{tabular}{lccccc}
\multicolumn{1}{c}{ Pretest } & \multicolumn{2}{c}{ Control Group } & \multicolumn{2}{c}{ Experimental Group } \\
\multicolumn{1}{c}{ Categories } & $\begin{array}{c}\text { Score } \\
\text { Ranges }\end{array}$ & Frequency & Percent (\%) & Frequency & Percent (\%) \\
Very Good & $20-16$ & 2 & 8.33 & 1 & 4.17 \\
Good & $15-11$ & 11 & 45.83 & 11 & 45.83 \\
Fair & $10-6$ & 11 & 45.83 & 11 & 45.83 \\
Poor & $5-0$ & 0 & 0.00 & 1 & 4.17 \\
Total: & & 24 & 100.00 & 24 & 100.00
\end{tabular}

traditional approach was implemented in the control group while experimental was treated with literature circle strategy.

Table 3. Posttest Performances of the Control and Experimental Groups

\begin{tabular}{lccccc}
\multicolumn{1}{c}{ Pretest } & \multicolumn{2}{c}{ Control Group } & \multicolumn{2}{c}{ Experimental Group } \\
\multicolumn{1}{c}{ Categories } & $\begin{array}{c}\text { Score } \\
\text { Ranges }\end{array}$ & Frequency & Percent (\%) & Frequency & Percent (\%) \\
Very Good & $20-16$ & 0 & 0.00 & 5 & 20.83 \\
Good & $15-11$ & 17 & 70.83 & 19 & 79.17 \\
Fair & $10-6$ & 7 & 29.17 & 0 & 0.00 \\
Poor & $5-0$ & 0 & 0.00 & 0 & 0.00 \\
Total: & & 24 & 100.00 & 24 & 100.00
\end{tabular}

Both groups improved in their posttest performances, as shown in Table 3. Most of the subjects in the control group, which garnered $70.83 \%$ in good category, made a slight increase in its performance insignificantly. However, being compared to the experimental group makes a major comparison. Five (5) or $20.83 \%$ of the subjects under the experimental group achieved very good category while the rest of the subjects which garnered $79.17 \%$ were under good category. It justifies that most of the 
subjects' scores under this group have increased significantly.

The results also highlight that there were subjects from the control group who still belong to fair category while the experimental group progresses only from good and very good categories.

The utmost improvement of the results among subjects under the experimental group, as shown in Table 3, positively implies the effectiveness of the literature circle strategy in improving critical thinking skills. The cooperative notion the strategy implicates is best backboned by Vygotsky's Zone of Proximal Development theory. It can be drawn from the result that the potential level of less competent subjects was developed because of social interaction from peers and adult's succor (McLeod, 2018).

Because the strategy is a peer-led discussion, it ignited subjects' interest to come up with questions driven from the text and critically expressed and valued each other's perspectives to these questions (Stabile, 2009). This also gave the subjects an inner drive to do things on their own and encourage thoughtful discussions (Ericson, 2001). Based on this concept, subjects were intrinsically motivated, which explains why they acquired higher levels of engagement and performance, and this idea is fully supported by Deci and Ryan's Self-determination Theory (Ryan \& Deci, 2000).

\subsection{Third Sub-Problem: Difference Between the Pretest Performances of the Control and Experimental Groups}

Table 4 presents the results of the test of significance of the differences between the pretest performances of the control and experimental groups. This is to measure if the strategy implemented in a certain group made a great impact in increasing students' critical thinking skills in reading.

Table 4. Difference Between the Pretest Performances of the Control and Experimental Groups

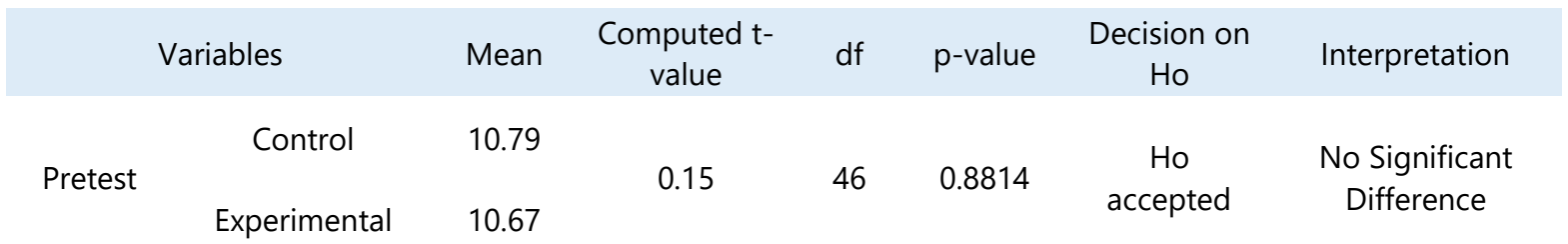

A t-test was used to find if there is a significant difference between the means of two groups. The computed t-value of both groups is 0.15 , with a corresponding $p$-value of 0.8814 . The $p$-value is greater than 0.05 level of significance, hence, the null hypothesis is accepted. It implies that there is no significant difference between the pretest performances of the control and experimental groups.

The research subjects of both groups yield similar results or mean scores and similar performances from the given pretest. This further validates that the subjects were equally divided according to their age, gender, and final grade in English 2. Both subjects, as well, driven from the result, do have a similar intellectual capacity or critical thinking skill to analyze and understand the given story of "Dead Stars."

\subsection{Fourth Sub-Problem: Difference Between the Pretest and Posttest Performances of the Control and Experimental Groups}

The results of the test of significance of the differences between the pretest and posttest performances of the control and experimental groups were presented in Table 5.

Table 5. Difference Between the Pretest and Posttest Performances of the Control and Experimental Groups

\begin{tabular}{|c|c|c|c|c|c|c|c|}
\hline Variable & & Mean & $\begin{array}{c}\text { Computed } \\
\text { t-value }\end{array}$ & df & $\mathrm{p}$-value & $\begin{array}{c}\text { Decision on } \\
\text { Ho }\end{array}$ & Interpretation \\
\hline Control & $\begin{array}{l}\text { Pretest } \\
\text { Posttest }\end{array}$ & $\begin{array}{l}10.79 \\
11.79\end{array}$ & -1.19 & 46 & 0.2402 & Ho accepted & $\begin{array}{c}\text { No Significant } \\
\text { Difference }\end{array}$ \\
\hline Experimental & $\begin{array}{l}\text { Pretest } \\
\text { Posttest }\end{array}$ & $\begin{array}{l}10.67 \\
13.96\end{array}$ & -4.79 & 46 & $<0.0001$ & Reject Ho & $\begin{array}{l}\text { Significantly } \\
\text { Different }\end{array}$ \\
\hline
\end{tabular}

The results tabulated in Table 5 showed the overall performances of the control group during the pretest and posttest which yield no significant difference. The research subjects' scores or critical thinking skills in reading have not improved that much 
even after the traditional approach in teaching literature has been implemented during the research process. Based on the data gathered, the lecture-based approach utilized in control group has increased its performance but still doesn't yield great impact in enhancing subjects' critical thinking skills in reading. Hence, there is no significant difference in their performance between pretest and posttest.

On the other hand, the results garnered by subjects under experimental group posted a significant difference between their pretest and posttest performances. This implies that the scores obtained in the experimental group showed a significant increase after the literature circle strategy in improving critical thinking skills has been implemented. With this notion, the strategy used in the experimental group helped in boosting subjects' performance as well as critical thinking skills in reading. This also showcased the effectiveness of the literature circle strategy compared to the traditional approach.

The results further conform to the idea of Brown (2009) who asserted that the literature circle is an excellent practice for analytical skills which helps learners become critical thinkers. When subjects immerse themselves in the process, they scrutinize the text, look for connections to the real world, make cultural assumptions towards the characters and to the author, situate themselves of why characters behave as they do and evaluate interpretations in a context-based manner.

\subsection{Fifth Sub-Problem: Difference Between the Posttest Performances of the Control and Experimental Groups}

The results of the test of significance of the differences between the posttest performances of the control and experimental groups were shown in Table 6.

Table 6. Difference Between the Posttest Performances of the Control and Experimental Groups

\begin{tabular}{|c|c|c|c|c|c|c|c|}
\hline & riables & Mean & $\begin{array}{l}\text { Computed t- } \\
\text { value }\end{array}$ & $d f$ & $\mathrm{p}$-value & $\begin{array}{c}\text { Decision on } \\
\text { Ho }\end{array}$ & Interpretation \\
\hline Posttest & $\begin{array}{c}\text { Control } \\
\text { Experimental }\end{array}$ & $\begin{array}{l}11.79 \\
13.96\end{array}$ & -3.07 & 46 & 0.0036 & Reject Ho & $\begin{array}{c}\text { Significantly } \\
\text { Different }\end{array}$ \\
\hline
\end{tabular}

The results yielded in Table 6 were gathered after different approaches in teaching literature to enhance critical thinking skills were implemented in control and experimental groups. The traditional approach and literature circle strategy were utilized respectively.

The computed $t$-value of both groups is -3.07 with a corresponding $p$-value of 0.0036 . The $p$-value is lesser than 0.05 level of significance, hence, the null hypothesis is rejected. This asserts that the performances between control and experimental groups displayed significant differences. Additionally, based on the mean, the experimental group which utilizes literature circle strategy obtained higher result than the control group.

The findings further imply that the literature circle used in the experimental group is better and more effective than the traditional. The cooperative learning strategy offers of which students work together in small groups, to accomplish a shared set of learning goals aided in maximizing their own and each other's learning (Johnson \& Johnson, 2005). On how the strategy works are greatly structured and based on cooperative learning theory of Johnson and Johnson (2008). Its success was greatly explained and hereby executed which explains that to have a high success rate, groups must consist of a heterogeneous set of skills and knowledge. Centered on the results tabulated in Table 6 and based on this notion, it was evident that the more skills engaged when students interact with each other, the higher their achievements will be.

\section{Conclusion and Recommendations}

The findings of this study showed that literature circle effectively develops critical thinking skills of students. Events, characters, experiences and other feelings of what students read in the text are shared as resources for independent learning.

The collaborative learning it offers ignited student's inner desire to read at the same time to engage more in learning resulting in their high level of performance. Students were able to formulate questions driven from the text and critically express and compare it towards each other's perspectives. They were able to evaluate information and ideas, reflect the text's validity and comprehend text beyond from what has been read. Hence, refining their critical thinking skills. Also, utilizing literature circles give students freedom of discussion in connecting text to their viewpoints. It paved the way for students to be in charge of their discussions of the text and learning. These show the nature of the literature circle and its advantages upon implementation.

More importantly, this study contributes to other researchers out there who are teachers by profession in giving them another perspective in teaching literature effectively in the classroom. It will help them address students' lack of incentive to read and to have students exercise higher-order thinking skills. It also paved the way to maximize students' engagement toward learning literature for teachers act as a facilitator within the process. Related studies concerning literature circles are lesser applied and studied in the Philippine context. Hence, this study can encourage school administrators to include the strategy in teaching 
literature. The administration will also realize that the problem issued is evident and must be given the utmost care.

In light of the findings of the study, the following recommendations are given:

1. Possible topics for future researches:

1.1. selection of non-fiction texts using literature circle in enhancing critical thinking skills,

1.2. literature circle strategy in enriching one's vocabulary, and

1.3. utilizing the literature circle strategy to enhance intrinsic motivation to read among college students.

1.4. applying literature circle in an online class

2. Practice literature circle strategy inside the classroom.

3. Let students do collaborative work when assigning reading activities.

4. As educators, formulate questions that would allow students to think beyond what is read.

\section{References}

[1] Ashman, A. \& Gillies, R. (Eds.). (2003). Cooperative learning: The social and intellectual outcomes of learning in groups. Routledge.

[2] Brown, H. (2009). Literature circles for critical thinking in global issues classes. The Language Teacher, 33(10), 16-17.

[3] Daniels, H. (2002). Literature circles: Voice and choice in book clubs and reading groups. Stenhouse Publishers. Retrieved November 12, 2002 from https://books.google. com.ph/books?id=hsIUp1-k5-8C\&f=false.

[4] Deci, E. L. \& Ryan, R. M. (Eds.). (2004). Handbook of self-determination research. University Rochester Press.

[5] Ericson, B. O. (2001). Teaching Reading in High School English Classes. National Council of Teachers of English, Urbana, IL.

[6] Fisher, A. (2011). Critical thinking: An introduction. Cambridge University Press. Retrieved September 22, 2011 from https://books.google.com.ph/books?id=wMhBQ0WdjF4C.

[7] Irawati, D. (2016). Effectiveness of literature circles on students' reading comprehension.IJOLTL: Indonesian Journal of Language Teaching and Linguistics, 1(3), 179-192.

[8] Johnson, D. W., Johnson, R. \& Holubec, E. (2013). Cooperation in the classroom (9th ed.). Interaction Book Company.

[9] Johnson, D. W. \& Johnson, R. T. (2005). New developments in social interdependence theory. Genetic, Social, and General Psychology Monographs, 131(4), 285-358.

[10] Johnson, R. T. \& Johnson, D. W. (2008). Active learning: Cooperation in the classroom. The Annual Report of Educational Psychology in Japan, 47, 29-30.

[11] Karatay, H. (2017). The Effect of literature circles on text analysis and reading desire. International Journal of Higher Education, 6(5), 65-75.

[12] Kurland, D. (2000). Critical reading and critical thinking. Retrieved June 11, 2000 from https://www.cgc.edu/Academics/LearningCenter/Writing/ Documents/Specific\%20Genres/Critical\%20Thinking\%20(3\%20pg).pdf.

[13] Lantolf, J. P. (Ed.). (2000). Sociocultural theory and second language learning (Vol. 78, No. 4). Oxford University Press. Retrieved March 16, 2000 from https://books.google.com.ph/books?id=iwsewZKSMC.

[14] Legault, L. (2017). Self-determination theory. Encyclopedia of Personality and Individual Differences, 21(2), 1-9.

[15] Liao, M. H. (2009). Cultivating critical thinking through literature circles in EFL context. Spectrum: Ncue Studies in Language, Literature, Translation, (5), 89-115.

[16] Mata, J., Silva, M. N., Vieira, P. N., Carraça, E. V., Andrade, A. M., Coutinho, S. R. \& Teixeira, P. J. (2009). Motivational "spill-over" during weight control: Increased self-determination and exercise intrinsic motivation predict eating self-regulation. Health Psychology, 28(6), 709.

[17] McCafferty, S. G., Jacobs, G. M. \& Iddings, A. C. (Eds.). (2006). Cooperative learning and second language teaching. Cambridge University Press. Retrieved August 14, 2006 from https://books.google.com.ph/ books?i d=_QVte8KUNzwC.

[18] McConnell, D. (2014). Implementing computing supported cooperative learning. Routledge.

[19] McLeod, S. (2018). Lev Vygotsky. Simply psychology. Retrieved August 5, 2018 from https://www.simplypsychology.org/ygotsky.html.

[20] McPeck, J. E. (2016). Critical thinking and education. Routledge.

[21] Moses, A. (2009). How to create a classroom literature circle. Retrieved November 23, 2009 from https://www.edutopia.org/literature-circlesclassroom-book-discussion-how-to.

[22] Niemiec, C. P. \& Ryan, R. M. (2009). Autonomy, competence, and relatedness in the classroom: Applying self-determination theory to educational practice. Theory and Research in Education, 7(2), 133-144.

[23] Noe, K. S. (2013). Literature circle center. Retrieved April 27, 2013 from https://www.litcircles.org/index.html.

[24] Paul, R. \& Elder, L. (2019). The miniature guide to critical thinking concepts \& tools. Rowman \& Littlefield. Retrieved June 1, 2019 from https://books.google.com.ph/b ooks?id=-DSbDwAAQBAJ.

[25] Peterson, S. \& Belizaire, M. (2006). Another look at roles in literature circles. Middle School Journal, 37(4), 37-43.

[26] Roque A. P. (2016). Pressing on. PressReader, p. 10. Retrieved June 22, 2016 from https://www.pressreader.com/philippines/business-world.

[27] Ryan, R. M. \& Deci, E. L. (2000). Self-determination theory and the facilitation of intrinsic motivation, social development, and wellbeing. American Psychologist, 55(1), 68.

[28] Sandmann, A. \& Gruhler, D. (2007). Reading is thinking. International Journal of Learning, 13(10), 105-113.

[29] Seifert, K. \& Sutton, R. (2012). Educational psychology. Basic Books.

[30] Stabile, C. (2009). Are literature circles an effective reading strategy for struggling readers. Ohio University, Athens, OH. Unpublished master's thesis.

[31] Straits, W. \& Nicholas, S. (2006). Literature circles for science. Science and Children, 44(3), 52-55.

[32] Whittingham, J. (2014). Reading motivation: A study of literature circle. Academic Exchange Quarterly, 18(2), 1-5.

[33] Yang, A. (2002). Science fiction in the EFL class. Language Culture and Curriculum, 15(1), 50-60. 


\section{APPENDICES}

\section{APPENDIX A RESEARCH INSTRUMENTS}

I. MULTIPLE CHOICE. Encircle the letter of your choice.

1. A complex judgment between two women confronts Alfredo. Yet, he ended with someone whom his family betrothed him to. What aspect/s could account behind this conflict?

a. It leaves his love untroubled in the first place, no matter how tempting the situation is.

b. He realized that the love toward Julia is more genuine and is far distinct than what he felt to Esperanza.

c. The society has contributed most of the factor and what people might say matters him most.

d. He falls drastically in love with the other woman. He did not let society dehumanized him and be the master of his fate.

2. Esperanza's character, compared to any, modern woman has a different approach in confronting the issue.

a. Esperanza is banking on the fact that Alfredo is already committed to her and could not possibly leave her for another woman.

b. She has heard lots of rumors and awaits for an opportunity to make use of these for Alfredo's undoing.

c. She is scheming something in secrecy and plans not to confront Alfredo with the issue.

d. Esperanza believes that Alfredo will eventually lose his interest in the other woman.

3. In the arms of Julia, Alfredo is seemingly out of his character, from a relaxed and calm demeanor to a man bursting with energy and vitality. What could be the reason behind this abrupt change of behavior?

a. Dull moments and lack of excitement have enveloped the relationship between Esperanza and Alfredo, provoking the latter to experience something new.

b. When Alfredo is with Julia, he feels freedom away from the prying eyes of society.

c. Julia's character, compared to Esperanza, is more comfortable to be with, and he feels freedom.

d. Alfredo's inner desire of being vigorous and passionate, which are Julia's characters, has ignited him to go against what is right.

4. It is an unhappy marriage, yet Alfredo is still far from the reach of Esperanza. Why is Alfredo still longing for Julia after many years have passed?

a. Alfredo still cares about what Julia feels after the painful parting, the night Julia found out he was engaged.

b. He pins to the illusion of the past, which haunts him thinking of what could happen if they have rekindled the love they once had.

c. Julia had made the right decision for Alfredo, and this was not heartily accepted.

d. Alfredo would feel real happiness if Julia turned out to be his wife.

5. Esperanza believes in the 'regenerative virtue of institution, in their power to regulate feeling as well as to conduct.' Based on this notion, do you think Esperanza doesn't love Alfredo?
a. Yes, for she was not prone to indulge in unprovoked jealousies.
b. Yes, it's safe to say so, for she is in a relationship for moral obligation and social expectations.
c. No, for despite the situation, she never went out of her way to find another man.
d. No, it's safe to say so, for she never mistrusted Alfredo's feelings.

6. The story depicts a love triangle. Aside from choosing between two women, what could be the most underlying dilemma of Alfredo?

a. The choice between what he feels he should do and what he wants to do.

b. He is preoccupied imagining life with Julia Salas if they ended together.

c. He is much concerned with the whereabouts of Julia Salas. 
d. All of the above.

7. When Alfredo went to Julia's hometown, fate destined them to meet and had a small talk. Amid their conversation, Alfredo felt that something was missing. What could it be?

a. The appearance of Julia Salas that he once fascinated.

b. The feeling he has pinned on to Julia for a long time.

c. The vitality she once felt to Julia every time they meet.

d. The emotionless and undisturbed disposition they have felt.

8. Alfredo is aware of the causes of his change and the consequences he might be facing if he continues to deviate from the norms of society. According to him, what is the very reason why would men like him mismanaged their lives.
a. To try something new ignites their curiosity.
b. Temptations are lurking around the corner
c. Satisfying greed and desire for craving an immediate excitement pushed them to do thigs.
d. Temptations are lurking around the corner
e. The wild dreams and chances they always want to meet and satisfy.

9. Do the characters in the story portray a significant difference to the attributes people have today?
a. Yes, change is now happening, and all people disregard the views of society.
b. Yes, irrational emotions conflicting with the right decisions drive most of the people nowadays.
c. No, the norms displayed in society initiate the decisions.
d. No, all people still believe in infidelity and have high regard for marriage.

10. The author sets the story in Don Julian's and Judge Del Valle's house. What does it try to imply?
a. The society is patriarchal, and it foreshadows the social make-up.
b. Don Julian and Judge Del Valle are prominent and influential people in town.
c. It signifies Alfredo's wealth and influence in society.
d. Don Julian and Judge Del Valle dominated the forms and morals of society.

11. The social set-up of the story affects the decisions the characters have made. Describe the society the characters are in.
a. People live up to the expectations of society.
b. Society highly viewed courtship, marriage, and fidelity.
c. It requires people to make sacrifices of themselves to conform to the norms and culture of the society.
d. All of the above.

12. The love of Alfredo for Julia is like a dead star. What does this mean?
a. The love ignited between Alfredo and Julia is forbidden.
b. Alfredo's love for Julia is eternal, and fate cannot change it.
c. It refers to an illusion of transient love out from curiosity of what could have been if it happened.
d. Alfredo's love is just one-sided and is fantasized by him alone.

13. Why is Alfredo, one of the main characters of the story, made a lawyer by profession?
a. Lawyers make a good profit.
b. Alfredo, through his profession, has influenced society.
c. The profession paved the way for Alfredo for Esperanza to trust him.
d. Lawyers are known to be wise and objective in making decisions and so as Alfredo.

14. What situation do characters portray a man vs. society type of conflict?

a. When Esperanza believes in the 'regenerative virtue of institution, in their power to regulate feeling as well as 
conduct.'

b. It refers to people's sentiments when a long engagement will break on the eve of the wedding.

c. Both $\mathrm{a}$ and $\mathrm{b}$ are correct answers.

d. Alfredo was torn between doing what is right and what is in his heart.

15. What event displays man vs. man conflict?

a. Alfredo was torn between doing what is right and what is in his heart.

b. When Esperanza believes in the 'regenerative virtue of institution, in their power to regulate feeling as well as conduct.'

c. It refers to people's sentiments when a long engagement will break on the eve of the wedding.

d. Both $\mathrm{a}$ and $\mathrm{b}$ are correct answers.

16. How did the story start?

a. He had gone neighboring with Don Julian to Judge Del Valle's house and met Julia Salas. Coming to the judge's house became often and realized he was in love with Julia in spite of his engagement with Esperanza.

b. Alfredo and Esperanza got married. After eight years, he was searching for a lady named Brigida Samuy-a lady important for his defense in the court-in Sta. Cruz, Julia's hometown.

c. At Don Julian's house, Carmen was asking Don Julian about Alfredo and Esperanza. Alfredo reminisced how he met Julia Salas.

d. After the procession for The Lady of Sorrows, Alfredo caught up with Julia and congratulated him for the wedding. It traps Alfredo in a complicated situation and decision.

17. What is the rising action of the story?

a. Alfredo and Esperanza got married. After eight years, he was searching for a lady named Brigida Samuy-a lady important for his defense in the court-in Sta. Cruz, Julia's hometown.

b. After the procession for The Lady of Sorrows, Alfredo caught up with Julia and congratulated him for the wedding. It traps Alfredo in a complicated situation and decision.

c. At Don Julian's house, Carmen was asking Don Julian about Alfredo and Esperanza. Alfredo reminisced how he met Julia Salas.

d. He had gone neighboring with Don Julian to Judge Del Valle's house and met Julia Salas. Coming to the judge's house became often and realized he was in love with Julia in spite of his engagement with Esperanza.

18. What could be the climax of the story?

a. He had gone neighboring with Don Julian to Judge Del Valle's house and met Julia Salas. Coming to the judge's house became often and realized he was in love with Julia in spite of his engagement with Esperanza.

b. Alfredo and Esperanza got married. After eight years, he was searching for a lady named Brigida Samuy-a lady important for his defense in the court-in Sta. Cruz, Julia's hometown.

c. After the procession for The Lady of Sorrows, Alfredo caught up with Julia and congratulated him for the wedding. It traps Alfredo in a complicated situation and decision.

d. Julia didn't want Alfredo not to honor his understanding with Esperanza. She said goodbye and went home to Esperanza. There, she has said the last word.

19. What theme does the story try to convey to the readers?

a. It is never good to have a dalliance with another woman.

b. One must be deliberate in deciding.

c. People are blind in seeking the hedonistic pursuit of things that they once romanticized.

d. Always pursue and do what you desire.

20. Why is the story, Dead Stars, still relevant today?

a. The story has been the favorite topic for discussion in literature subjects.

b. The story depicts the innate nature of humans. 
c. The characters' features and responses to the society are reflected.

d. The societal set-up of the story reflects what we have today.

Answer Key:

\begin{tabular}{|l|l|l|l|l|}
\hline 1. C & 5. B & 9. B & $13 . \mathrm{D}$ & $17 . \mathrm{D}$ \\
\hline 2. A & 6. A & 10. A & $14 . \mathrm{C}$ & $18 . \mathrm{C}$ \\
\hline 3. D & 7. B & 11. D & $15 . \mathrm{A}$ & $19 . \mathrm{C}$ \\
\hline 4. B & 8. C & 12. C & 16. C & 20. B \\
\hline
\end{tabular}

APPENDIX B

RELIABILITY TEST RESULT

Table 7: Cronbach's Alpha Reliability Test Result

\begin{tabular}{|c|c|c|c|c|c|c|c|c|c|c|c|c|c|c|c|c|c|c|c|c|c|}
\hline & Items & & & & & & & & & & & & & & & & & & & & \\
\hline & 1.1 & 1.2 & 1.3 & 1.4 & 1.5 & 1.6 & 1.7 & 1.8 & 1.9 & I.10 & I.11 & I.12 & l.13 & l.14 & 1.15 & I.16 & l.17 & 1.18 & 1.19 & 1.20 & Total \\
\hline Persons & 0 & 0 & 1 & 0 & 0 & 1 & 0 & 1 & 0 & 1 & 1 & 0 & 0 & 1 & 0 & 1 & 0 & 1 & 0 & 0 & 8 \\
\hline S.2. & 0 & 0 & 0 & 0 & 0 & 0 & 0 & 0 & 0 & 0 & 0 & 0 & 0 & 0 & 0 & 0 & 0 & 0 & 0 & 0 & 0 \\
\hline 5.3 & 0 & 0 & 1 & 1 & 0 & 1 & 1 & 1 & 1 & 1 & 0 & 0 & 1 & 0 & 1 & 1 & 1 & 1 & 0 & 0 & 12 \\
\hline S.4. & 1 & 1 & 1 & 1 & 0 & 0 & 0 & 1 & 1 & 1 & 1 & 0 & 1 & 1 & 1 & 1 & 1 & 0 & 0 & 0 & 13 \\
\hline 5.5 & 0 & 1 & 1 & 1 & 0 & 0 & 0 & 0 & 0 & 1 & 1 & 0 & 1 & 0 & 0 & 0 & 0 & 0 & 0 & 0 & 6 \\
\hline 5.6 & 0 & 0 & 1 & 0 & 0 & 1 & 1 & 1 & 0 & 0 & 0 & 0 & 0 & 0 & 0 & 0 & 0 & 0 & 0 & 0 & 4 \\
\hline S.7L & 0 & 0 & 1 & 1 & 0 & 1 & 1 & 1 & 1 & 1 & 0 & 1 & 1 & 0 & 0 & 0 & 0 & 0 & 0 & 0 & 9 \\
\hline S.8 & 1 & 1 & 0 & 1 & 0 & 1 & 1 & 1 & 0 & 0 & 1 & 1 & 0 & 1 & 1 & 1 & 1 & 0 & 0 & 0 & 12 \\
\hline 5.9 & 1 & 1 & 0 & 1 & 1 & 1 & 0 & 1 & 1 & 1 & 1 & 0 & 1 & 1 & 1 & 1 & 0 & 0 & 0 & 0 & 13 \\
\hline$\$ .10$ & 1 & 1 & 1 & 1 & 0 & 1 & 0 & 0 & 1 & 1 & 0 & 0 & 1 & 1 & 1 & 0 & 0 & 1 & 0 & 0 & 11 \\
\hline S.11 & 0 & 0 & 1 & 0 & 1 & 1 & 1 & 1 & 1 & 0 & 1 & 0 & 0 & 1 & 1 & 0 & 0 & 1 & 0 & 0 & 10 \\
\hline S.12 & 0 & 1 & 0 & 0 & 1 & 0 & 0 & 1 & 0 & 0 & 0 & 0 & 0 & 0 & 0 & 0 & 0 & 0 & 1 & 0 & 4 \\
\hline S.13 & 1 & 0 & 0 & 0 & 0 & 0 & 1 & 1 & 1 & 1 & 0 & 0 & 0 & 1 & 1 & 0 & 1 & 1 & 0 & 0 & 9 \\
\hline S.14 & 1 & 1 & 1 & 1 & 0 & 0 & 0 & 1 & 0 & 1 & 1 & 0 & 0 & 1 & 1 & 0 & 1 & 1 & 1 & 0 & 12 \\
\hline S.15 & 1 & 1 & 1 & 1 & 0 & 0 & 1 & 1 & 0 & 0 & 0 & 0 & 0 & 1 & 1 & 0 & 1 & 1 & 1 & 1 & 12 \\
\hline 5.16 & 1 & 1 & 1 & 1 & 0 & 0 & 1 & 0 & 0 & 0 & 1 & 0 & 0 & 1 & 1 & 0 & 0 & 1 & 0 & 0 & 9 \\
\hline 5.17 & 0 & 0 & 1 & 1 & 1 & 0 & 1 & 1 & 1 & 1 & 1 & 1 & 1 & 1 & 1 & 1 & 1 & 1 & 1 & 1 & 17 \\
\hline 5.18 & 0 & 0 & 0 & 0 & 0 & 1 & 1 & 1 & 1 & 1 & 1 & 0 & 0 & 1 & 0 & 1 & 0 & 1 & 0 & 0 & 9 \\
\hline 5.19 & 0 & 0 & 0 & 1 & 0 & 0 & 1 & 0 & 1 & 0 & 0 & 0 & 0 & 1 & 1 & 1 & 1 & 0 & 0 & 1 & 8 \\
\hline$\$ .20$ & 0 & 0 & 1 & 1 & 1 & 0 & 1 & 0 & 0 & 1 & 1 & 0 & 1 & 1 & 1 & 1 & 1 & 0 & 0 & 1 & 12 \\
\hline S.21 & 0 & 0 & 0 & 0 & 1 & 1 & 0 & 1 & 0 & 0 & 0 & 0 & 0 & 0 & 0 & 0 & 0 & 0 & 1 & 0 & 4 \\
\hline$\$ .22$ & 0 & 1 & 0 & 1 & 0 & 1 & 0 & 1 & 1 & 1 & 1 & 1 & 0 & 1 & 1 & 1 & 1 & 1 & 0 & 0 & 13 \\
\hline$\$ .23$ & 0 & 0 & 0 & 0 & 0 & 0 & 0 & 0 & 0 & 1 & 1 & 0 & 0 & 0 & 0 & 0 & 1 & 0 & 0 & 0 & 3 \\
\hline$\$ .24$ & 0 & 0 & 1 & 1 & 0 & 0 & 1 & 0 & 0 & 0 & 0 & 0 & 0 & 1 & 1 & 1 & 1 & 1 & 1 & 1 & 10 \\
\hline$\$ .25$ & 0 & 0 & 1 & 1 & 1 & 1 & 1 & 1 & 0 & 1 & 0 & 1 & 0 & 1 & 1 & 0 & 0 & 1 & 0 & 1 & 12 \\
\hline$\$ .26$ & 0 & 1 & 1 & 0 & 0 & 0 & 0 & 0 & 1 & 1 & 0 & 0 & 1 & 1 & 0 & 0 & 0 & 0 & 0 & 0 & 6 \\
\hline 5.27 & 0 & 1 & 0 & 1 & 0 & 1 & 0 & 0 & 1 & 0 & 0 & 0 & 0 & 0 & 0 & 0 & 0 & 1 & 0 & 0 & 5 \\
\hline$\$ .28$ & 0 & 0 & 1 & 1 & 0 & 1 & 1 & 1 & 1 & 1 & 0 & 0 & 0 & 1 & 1 & 1 & 0 & 1 & 0 & 1 & 12 \\
\hline 5.29 & 0 & 1 & 1 & 1 & 0 & 1 & 0 & 0 & 1 & 1 & 0 & 0 & 1 & 1 & 1 & 0 & 0 & 1 & 0 & 0 & 10 \\
\hline
\end{tabular}

Sum of item variances $=\quad 4.492$

Number of items = 20

\begin{tabular}{|l|c|}
\hline Cronbach's Alpha & 0.702 \\
\hline SEM & 2.005 \\
\hline SEM (Alternative formula) & 2.005 \\
\hline SEM $^{*}$ & 2.119 \\
\hline
\end{tabular}

Legend:

\begin{tabular}{|c|c|}
\hline Range & Interpretation \\
\hline$>0.9$ & Excellent \\
\hline$>0.8$ & Good \\
\hline$>0.7$ & Acceptable \\
\hline
\end{tabular}




\begin{tabular}{|c|c|}
\hline$>0.6$ & Questionable \\
\hline$>0.5$ & Poor \\
\hline$<0.5$ & Unacceptable \\
\hline
\end{tabular}

Table 7 shows the reliability test of the researcher-made test utilizing the Cronbach Alpha. The pilot test/dry run responses yield a Cronbach Alpha value of 0.702 . It indicates that the reliability of the test is acceptable and researcher-made instrument has passed the test.

\section{APPENDIX C INTERVENTION GUIDE QUESTIONS}

\section{Characters}

1. Describe each character. Descriptions must be used and supported with the events from the story.

2. What is the significance of the key for Pedro? For Soledad?

3. Why did Soledad think that the trunk can threaten her beautiful relationship with her husband?

4. Does Pedro love Soledad? Why does Pedro still keep the belongings of his dead wife?

5. Pedro somehow knew that this incident would always remain a shadow in their lives. Why does he think so?

6. Pedro's character seems silent after everything that had happened. What's the reason behind this?

7. Compare the love of Pedro between Soledad and his dead wife.

8. If you were Soledad, would you have done the same thing that she did? Explain your answer.

9. List all the attributes that can be reflected from each character and determine which traits should be practiced or not? Elaborate.

10. What character traits of Pedro and Soledad best reflect you? Explain.

\section{Setting}

1. Describe the setting or the societal set up of the story?

2. Does the setting give a hint of what could have happened along with the story? Support your answer

3. Compare the setting then and now.

4. Do the characters in the story portray a significant difference to the attributes people have today? Why?

Plot

1. Reflect on some of the events of the story in societal happenings and marriage life.

2. Narrate the events of the story
a. Exposition
b. Rising action
c. Climax
d. Falling Action
e. Resolution/ Denouement

3. What's the conflict of the story?

4. Give significant events that happened in the story.

5. If you were to change the plot, what could be your story?

\section{Symbols}

1. What does the small key symbolize?

2. List other words or visual images that can be symbolic. Explain and elaborate

3. The following are specific events in the story. Please interpret.

4. Does age play a significant role in how events turned out in the story? In what way?

\section{Theme}

1. What values can we get from the story?

2. Can these values be seen today? Support your answer.

3. Describe the message the story tries to portray.

4. What is the impact of the story on the readers? 


\begin{tabular}{|l|l|}
\hline \multicolumn{1}{|c|}{ Specific points in the narrative } & \multicolumn{1}{|c|}{ Interpretation } \\
\hline $\begin{array}{l}\text { "Sunday... quiet.. Peace... beauty everywhere. But a fierce } \\
\text { gnawing fear in the heart of a woman and bitter } \\
\text { smoldering resentment in a man's" }\end{array}$ & \\
\hline $\begin{array}{l}\text { A puzzled expression came into his eyes. First it was doubt } \\
\text { groping for truth, then amazement, and finally agonized } \\
\text { incredulity passed across his face. }\end{array}$ & \\
\hline $\begin{array}{l}\text { But somehow he knew that this incident would always } \\
\text { remain a shadow in their lives. }\end{array}$ & \\
\hline $\begin{array}{l}\text { She would explain sooner or later, she would be repentant, } \\
\text { perhaps she would even listen and eventually forgive her, } \\
\text { for she was young and he loved her. }\end{array}$ & \\
\hline $\begin{array}{l}\text {...dropped the small one back into his pocket. She watched } \\
\text { him fixedly as he did this. The smile left her face and a } \\
\text { strange look came into her eyes as she took the big key } \\
\text { from him without a word. }\end{array}$ & \\
\hline
\end{tabular}

APPENDIX D-1

PRETEST PERFORMANCES OF THE CONTROL AND EXPERIMENTAL GROUPS

Table 8: Data Gathered during Pretest Performances of the Control and Experimental Groups

\begin{tabular}{|c|c|c|c|}
\hline SUBJECTS (I) & CONTROL & SUBJECTS (II) & EXPERIMENTAL \\
\hline A & 16 & AA & 13 \\
\hline B & 15 & BB & 11 \\
\hline C & 8 & CC & 13 \\
\hline D & 12 & DD & 11 \\
\hline E & 13 & EE & 13 \\
\hline F & 7 & FF & 13 \\
\hline G & 16 & GG & 11 \\
\hline H & 12 & HH & 12 \\
\hline I & 9 & II & 10 \\
\hline J & 11 & JJ & 16 \\
\hline K & 14 & KK & 10 \\
\hline L & 9 & LL & 7 \\
\hline M & 10 & MM & 10 \\
\hline N & 6 & NN & 13 \\
\hline O & 13 & OO & 9 \\
\hline P & 13 & PP & 8 \\
\hline Q & 10 & QQ & 10 \\
\hline R & 12 & RR & 14 \\
\hline S & 9 & TT & 9 \\
\hline T & 12 & & 10 \\
\hline & 12 & & \\
\hline
\end{tabular}




\begin{tabular}{|c|c|c|c|}
\hline U & 12 & UU & 8 \\
\hline V & 6 & VV & 12 \\
\hline W & 7 & WW & 9 \\
\hline X & 7 & XX & 4 \\
\hline SUM & $\mathbf{2 5 9}$ & & $\mathbf{2 5 6}$ \\
\hline
\end{tabular}

APPENDIX D-2

POSTTEST PERFORMANCES OF THE CONTROL AND EXPERIMENTAL GROUPS

Table 9: Data Gathered during Posttest Performances of the Control and Experimental Groups

\begin{tabular}{|c|c|c|c|}
\hline SUBJECTS (I) & CONTROL & SUBJECTS (II) & EXPERIMENTAL \\
\hline$A$ & 15 & $\mathrm{AA}$ & 16 \\
\hline B & 15 & BB & 15 \\
\hline$C$ & 11 & $\mathrm{CC}$ & 13 \\
\hline$D$ & 13 & $\mathrm{DD}$ & 11 \\
\hline$E$ & 11 & $\mathrm{EE}$ & 12 \\
\hline $\mathrm{F}$ & 10 & $\mathrm{FF}$ & 16 \\
\hline G & 13 & GG & 15 \\
\hline $\mathrm{H}$ & 13 & $\mathrm{HH}$ & 14 \\
\hline 1 & 13 & II & 17 \\
\hline J & 14 & J & 19 \\
\hline $\mathrm{K}$ & 14 & KK & 13 \\
\hline$L$ & 14 & $\mathrm{LL}$ & 16 \\
\hline$M$ & 13 & $\mathrm{MM}$ & 11 \\
\hline $\mathrm{N}$ & 8 & NN & 15 \\
\hline 0 & 14 & OO & 11 \\
\hline$P$ & 15 & PP & 15 \\
\hline Q & 7 & QQ & 12 \\
\hline $\mathrm{R}$ & 12 & $\mathrm{RR}$ & 13 \\
\hline $\mathrm{S}$ & 15 & SS & 15 \\
\hline $\mathrm{T}$ & 11 & $\mathrm{TT}$ & 15 \\
\hline U & 6 & UU & 13 \\
\hline $\mathrm{V}$ & 10 & VV & 12 \\
\hline W & 7 & WW & 13 \\
\hline$x$ & 9 & $x X$ & 13 \\
\hline SUM & 283 & & 335 \\
\hline
\end{tabular}


APPENDIX E

\section{DOCUMENTATIONS OF PRETEST AND POSTTEST RESULTS}

\section{Sample Pretest and Posttest Results of the Control Group}
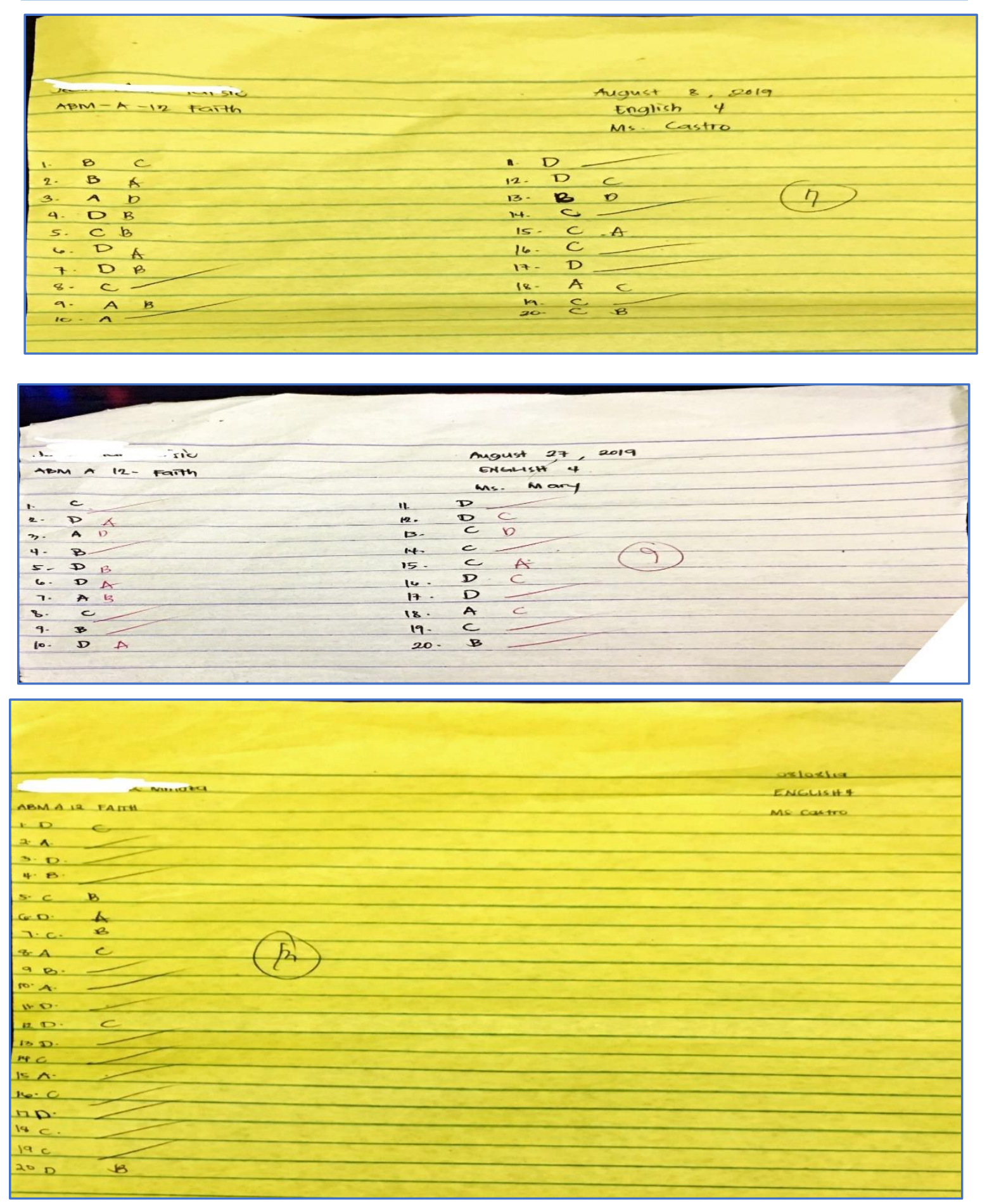


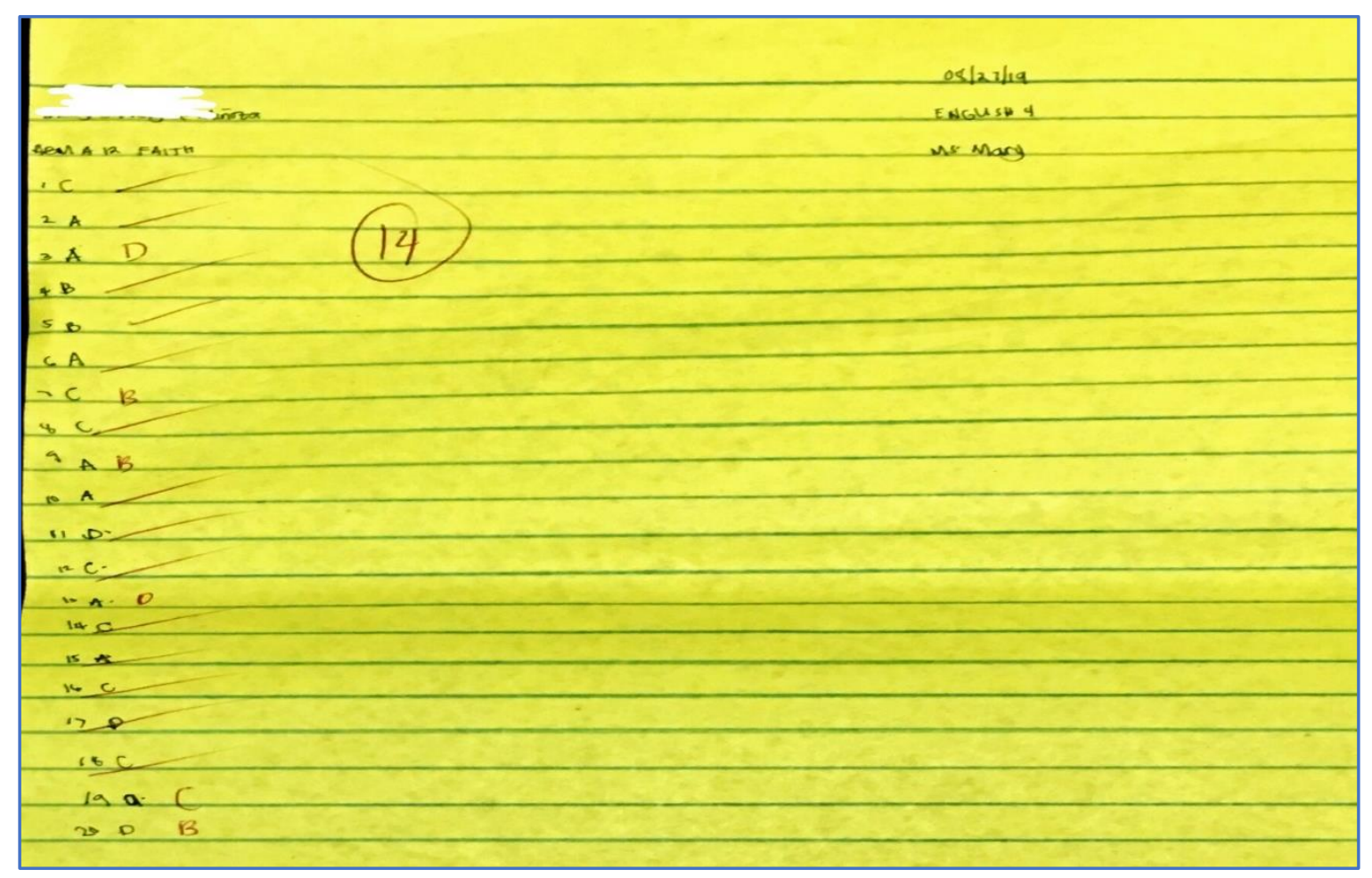

\section{Sample Pretest and Posttest Results of the Experimental Group}

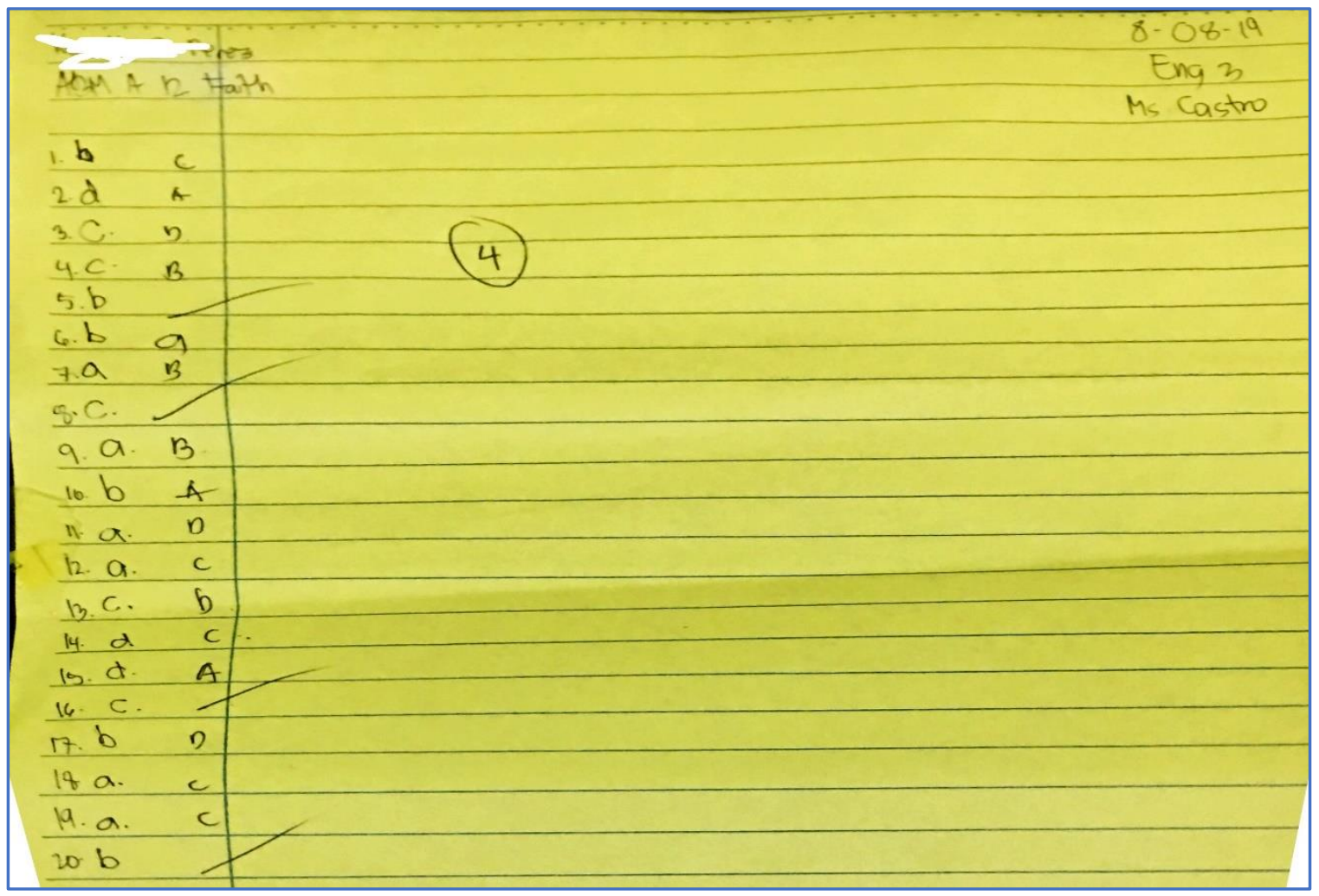



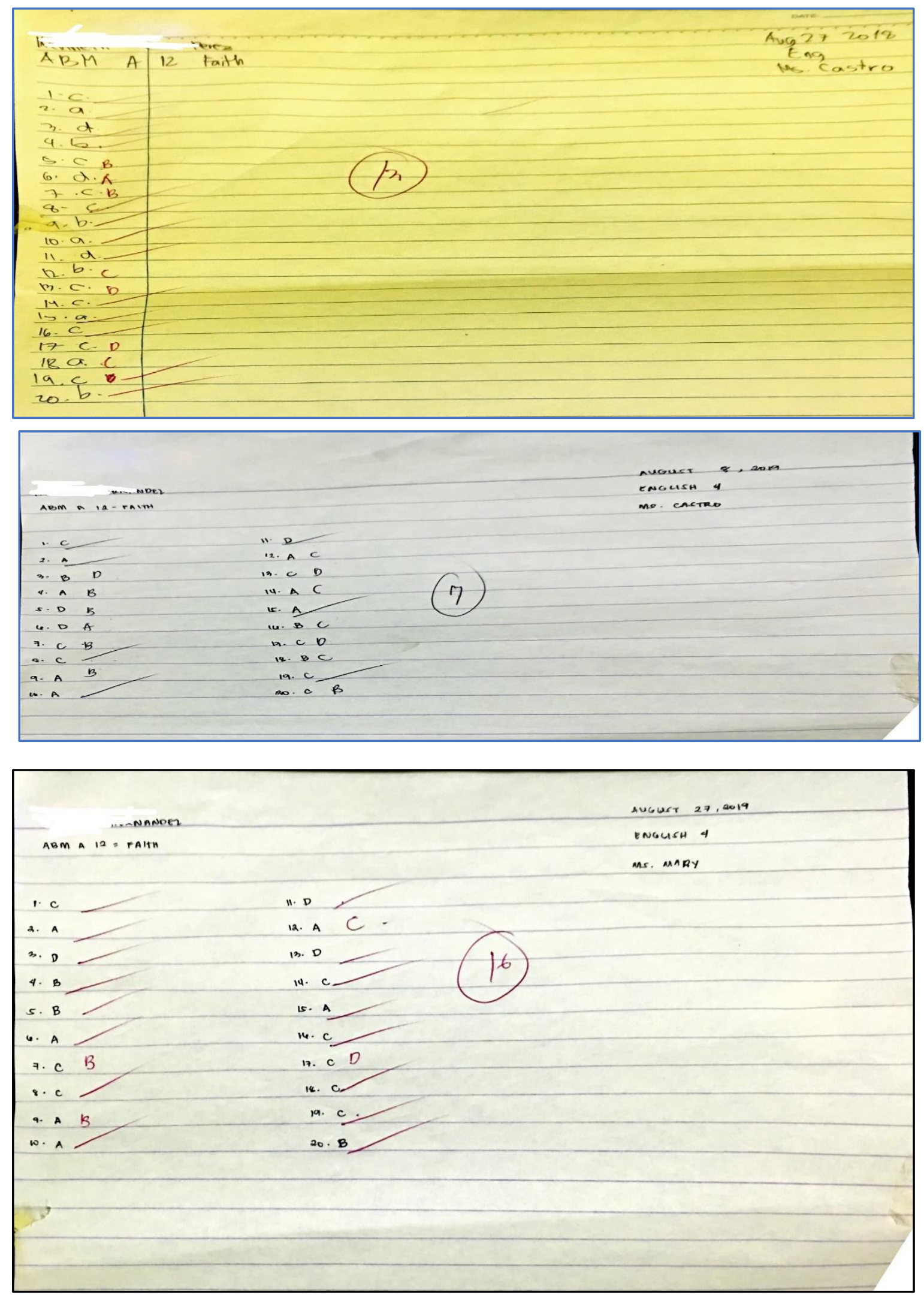